\title{
17- $\alpha$-ethynylestradiol alters conversion of $\alpha$-linolenic acid to longer chain PUFA in rat hepatocarcinoma cells
}

\author{
E. L. Holmes ${ }^{1}$, S. P. Hoile ${ }^{2}$, K. A. Lillycrop ${ }^{1}$ and G. C. Burdge ${ }^{2}$ \\ Faculty of Natural and Environmental Sciences and Faculty of Medicine, University of Southampton, \\ Southampton SO16 6YD, UK
}

Female human subjects and rats have higher DHA $(22: 6 n-3)$ status and greater capacity to convert $\alpha$-linolenic acid (18:3n-3) to the longer chain PUFA EPA $(20: 5 n-3)$ and $22: 6 n-3$ than males ${ }^{(1)}$. Previous studies have indicated that $18: 3 n-3$ is regulated by oestrogen. Increased exposure of male transsexuals to synthetic estrogens ${ }^{(2)}$ and use of an 17- $\alpha$ ethynylestradiol (EE ${ }_{2}$ )-based oral contraceptive pill increased 22:6n-3 status and synthesis compared with untreated individuals ${ }^{(3)}$. The aim of this study was to investigate the mechanism by which oestrogen alters $18: 3 n-3$ conversion.

Rat hepatocarcinoma CC1 cells were seeded at approximately $75 \%$ confluence and maintained in DMEM with $5 \%$ fetal bovine serum at $37^{\circ} \mathrm{C}$. Cultures were supplemented with ethyl-linolenate $(100 \mu \mathrm{M})$ and with $\mathrm{EE}_{2}(0-7 \mathrm{nM})$ for $72 \mathrm{~h}$. Cells were harvested by scraping into Hanks balanced salt solution. Total lipids were extracted with chloroform and methanol, transmethylated with methanolic sulphuric acid and the proportions of individual fatty acids were measured by $\mathrm{GC}^{(4)}$. In order to determine the effect of EE 2 on FADS 1 and 2 mRNA expression, cells treated for $72 \mathrm{~h}$ with either zero or $\mathrm{EE}_{2}(700 \mathrm{pM})$ and RNA was extracted using Trizol. cDNA was prepared and the levels of FADS 1 and FADS 2 mRNA were determined by real time RT-PCR ${ }^{(5)}$. Ct values were normalised to cyclophilin.

\begin{tabular}{|c|c|c|c|c|c|c|c|c|c|}
\hline & \multicolumn{8}{|c|}{$17 \alpha$-Ethynylestradiol concentration (pM) } & \multirow{3}{*}{ ANOVA $(P)$} \\
\hline & \multicolumn{2}{|c|}{0} & \multicolumn{2}{|c|}{70} & \multicolumn{2}{|c|}{700} & \multicolumn{2}{|c|}{7000} & \\
\hline & Mean & SD & Mean & $\overline{\mathrm{SD}}$ & Mean & SD & Mean & $\overline{\mathrm{SD}}$ & \\
\hline \multicolumn{10}{|c|}{ Proportion of fatty acids (g/100 g total fatty acids) } \\
\hline $18: 3 n-3$ & 10.8 & 1.6 & 12.1 & 1.6 & 11.3 & 1.0 & 10.0 & 0.8 & 0.12 \\
\hline $20: 5 n 3$ & $1.5^{*}$ & 0.2 & $0.8 \dagger$ & 0.2 & $1.5^{*}$ & 0.2 & $1.7 *$ & 0.1 & $<0.0001$ \\
\hline $22: 6 n-3$ & $1.9 *$ & 0.3 & $3.1 \dagger$ & 0.7 & $4.0 \dagger$ & 0.7 & $4.1 \dagger$ & 0.6 & $<0.0001$ \\
\hline \multicolumn{9}{|c|}{ mRNA expression $\left(\log _{10} \Delta \Delta \mathrm{Ct}\right)$} & $t$-test $(P)$ \\
\hline FADS 1 & $0.22^{\circ}$ & 0.19 & & & 0.68 & 0.17 & & & 0.014 \\
\hline FADS 2 & 0.38 & 0.13 & & & 0.78 & 0.37 & & & 0.09 \\
\hline
\end{tabular}

Treatment with $\mathrm{EE}_{2}$ did not alter 18:3n-3 concentration significantly at any of the concentrations tested. $70 \mathrm{pM} \mathrm{EE}_{2}$ decreased significantly the proportion of 20:5n-5 compared with untreated cells, but there was no difference at the higher $\mathrm{EE}_{2}$ concentrations. $\mathrm{EE}_{2}$ increased the proportion of 22:6n-3 significantly at all concentrations compared with untreated cells. $700 \mathrm{pM} \mathrm{EE}_{2}$ induced a significant increase in FADS 1, and a trend towards an increase in FADS 2 mRNA expression. Together these findings suggest that oestrogen modifies 18:3n-3 metabolism through a mechanism that involves altered transcription of FADS 1 and 2. One implication is that sex differences in PUFA metabolism involves differential regulation of transcription by sex hormones that may alter over the life course leading to age-related changes in PUFA status.

1. Burdge GC \& Calder PC (2006) Nutr Res Rev 19, 26-52

2. Giltay EJ, Gooren LJ, Toorians AW et al. (2004) Am J Clin Nutr 80, 1167-1174.

3. Burdge GC \& Wootton SA (2002) Br J Nutr 88, 411-420.

4. Burdge GC, Wright P, Jones AE et al. (2000) Br J Nutr 84, 781-787.

5. Burdge GC, Lillycrop KA, Phillips ES et al. (2009) J Nutr 139, 1054-1060. 